Board of Governors of the Federal Reserve System

International Finance Discussion Papers

Number 637

June 1999

\title{
ON THE DYNAMICS OF TRADE DIVERSION: EVIDENCE FROM FOUR TRADE BLOCS
}

\author{
Caroline L. Freund and John McLaren*
}

NOTE: International Finance Discussion Papers are preliminary materials circulated to stimulate discussion and critical comment. References in publications to International Finance Discussion Papers (other than an acknowledgment that the writer has had access to unpublished material) should be cleared with the author or authors. Recent IFDPs are available on the Web at www.bog.frb.fed.us. 


\title{
ON THE DYNAMICS OF TRADE DIVERSION: EVIDENCE FROM FOUR TRADE BLOCS
}

\author{
Caroline L. Freund and John McLaren*
}

\begin{abstract}
This paper studies the dynamics of trade reorientation experienced when a country joins a regional trade bloc. We find that the joining country's trade orientation toward bloc countries typically rises along an ' $S$ '-shaped path. We estimate the size, speed, and timing of this adjustment path for a 'typical' joining country, for four trade agreements. We find that, in the European Union (EU), the incumbent bloc countries' share of the joining country's trade typically rose by eighteen percentage points over the course of the adjustment; that this took twelve years; and that the adjustment began four years before the date of accession. MERCOSUR shows a similar pattern in progress, but NAFTA and EFTA are more idiosyncratic. We argue that the data provide strong evidence of anticipatory sunk investments made to prepare for accession.
\end{abstract}

Keywords: regionalism, sunk costs.

*International Finance Division of the Federal Reserve Board and Columbia University, respectively. The authors would like to thank Shaghil Ahmed, Jagdish Bhagwati, Allan Brunner, Steven Cameron, Pinelope Goldberg, Ann Harrison, Jim Harrigan, Andy Levin, Arvind Panagariya, Peter Neary, Dani Rodrik, John Rogers, Alan Winters, and seminar participants at the Federal Reserve Board, the NBER Summer Institute, University of Virginia, and the World Bank for helpful comments. They of course share no responsibility for any errors or deficiencies. Correspondence: Caroline Freund, International Finance Division, Federal Reserve Board, Washington D.C. 20551, e-mail: caroline.1.freund@frb.gov; John McLaren, Department of Economics, Columbia University, New York, NY 10027, e-mail: jem18@ columbia.edu. The views presented here are solely the responsibility of the authors and should not be interpreted as reflecting the views of the Board of Governors of the Federal Reserve System or any other person associated with the Federal Reserve System. 


\section{Introduction}

This paper studies the dynamics of trade reorientation experienced when a country joins a regional trade bloc. Specifically, when a country joins a regional trade bloc, the share of its trade that is accounted for by bloc countries naturally rises, with a path that is typically characterized, roughly, by an 'S' shape. The same pattern is exhibited by trade intensity indices, which control for growth of total bloc trade relative to world trade. We estimate the size, speed, and timing of the adjustment for a typical joining country, for four regional trade agreements.

In brief, for the European Union (EU), we find that the incumbent bloc countries' share of the joining country's trade typically rose by eighteen percentage points over the course of the adjustment; that this took twelve years; and that the adjustment began four years before the date of accession. In the case of the North American Free Trade Agreement (NAFTA) and the Common Market of the South (MERCOSUR), the adjustment is still in progress, with MERCOSUR exhibiting the most rapid rise in trade shares. The European Free Trade Agreement (EFTA) is a special case, in that most of its members later left; the trade share curve is, accordingly, hump shaped, with shares falling slowly once the bloc started disbanding.

This exercise has three main motivations. First, as a simple matter of positive economics, it is useful to be able to answer the question, "How long does it take for a country to adjust fully to the change in trade policy implied by accession to a regional trade agreement?" In analyzing the effects of a given agreement which has recently been concluded, it is useful to know how long the public must wait before the "long term" effects can be said to have arrived. As noted, estimates in this paper suggest that the full reallocation from a regional trade agreement may take as long as twelve years. $^{1}$

\footnotetext{
${ }^{1}$ At the same time, we reaffirm that the effect on trade flows of trade agreements between countries apparently
} 
Second, the demonstration of such a long and gradual adjustment path underlines the importance of adjustment costs in industrial response to trade policy changes. ${ }^{2}$ This has the important implication that once an economy joins a trade bloc, its structure may be permanently altered. This has been argued by Eichengreen and Irwin (1998), who demonstrated a strong empirical effect of lagged bilateral trade on current bilateral trade after controlling for country-pair characteristics, and interpreted this as the result of sunk, partner-specific investments. However, this interpretation was somewhat muddied, as Wonnacott (1998) points out, by the possibility that the lagged trade variable simply proxies for unmeasured, persistent comparative advantage variables. The gradual adjustment path we document is inconsistent with this view, and thus forcefully strengthens Eichengreen and Irwin's (1998) interpretation. ${ }^{3}$

Third, the results provide evidence of sunk investments made in anticipation of accessions. A considerable body of recent theory suggests that the normative analysis of trade policy decisions is greatly affected by the possibility that some of the reallocations they cause may take the form of anticipatory investment. For example, Staiger and Tabellini (1989) show that private-sector anticipatory investments can magnify the inefficiencies of distortionary trade policy. Maggi and Rodriguez-Clare (1998) show that such inefficiencies can be an important motivation for trade agreements in the case of a government susceptible to interest-group influence. McLaren (1997) shows that the bargaining-power effects of anticipatory investment can rob small-country partners already close to free trade can be quite large. In some of the examples (such as Portugal's accession to the EC), trade between the country and the block was already tariff- free, but subject to modest non-tariff barriers. Nonetheless, joining the EC caused a large reorientation of Portuguese trade toward EC countries.

${ }^{2}$ See Mussa (1978) for the canonical theory treatment, and Dehejia (1995) and Levy and van Wijnbergen (1994) for some implications for trade policy design.

${ }^{3}$ It has also been shored up by Roberts and Tybout's (1997) important firm-level study, which documents hysteresis effects of exporting in Columbian data. 
of much (or even all) of the surplus from trade agreements. Freund (1998) shows that strategic oligopolistic investments in anticipation of a preferential trade agreement can improve the welfare effect of the agreement.

Despite the importance of anticipatory investments in theory, evidence that they are important in practice has been in short supply. ${ }^{4}$ Estimates in this paper suggest that in the case of the EU, the reallocation of resources within a joining country have typically begun four years before the accession date, with one-third of the reallocation occurring before that date. It will be argued that the most plausible interpretation of this is that it is at least largely due to anticipatory investments.

It should be underlined that we are certainly making no claim to be estimating a structural relationship, and the estimated parameters have no direct interpretation in terms of tastes, technology, or welfare. The exercise is simply an attempt to summarize several important episodes in postwar trade history, using a convenient parametrization. Nonetheless, since theory models have implications for the way history will unfold qualitatively, we can make some inferences related to the theory from even such a simple descriptive exercise. The inferences that we suggest are that adjustment costs and anticipatory investment both are highly important empirically, and not merely theoretical possibilities.

Section 2 reviews the history of the trade blocs in question. The patterns of adjustment in the data are demonstrated qualitatively in Section 3. Section 4 quantifies these patterns. Section 5 discusses alternative interpretations of the finding that adjustment begins before accession, namely, the possibility that an exogenous reorientation of trade may have led to accession (the 'reverse causation' interpretation), or that accession was preceded by a series of minor agreements (the 'stepping stone' interpretation). Section 6 offers concluding comments.

\footnotetext{
${ }^{4}$ Winters (1984) is an exception; he notes that "a very strong case can be made for acknowledging anticipations [when Britain joined the EC] and including 1972 as the integration year" (p. 108).
} 


\section{History}

A thumbnail narrative of the trade blocs in question will be useful to keep track of the subsequent discussion. We attempt here to present only the details crucial for our purposes, and point out appropriate sources of more detailed accounts for the interested reader.

\subsection{The European Union}

The 1957 Treaty of Rome established the European Economic Community (EEC), which became effective as of 1958 and comprised Belgium, Luxembourg, France, Germany, Italy, and the Netherlands. ${ }^{5}$ It provided for broad liberalization of trade between members, including a gradual but complete elimination of internal tariffs completed by 1968, and a unified external tariff policy. However, the EEC had been preceded by two prominent movements toward integration: the European Coal and Steel Community (ECSC), formed in 1951 between the six that later formed the EEC; and the Benelux Union, the first customs union in Europe, formed in 1948 between Belgium, Luxembourg, and the Netherlands.

The Community was expanded in three waves. ${ }^{6}$ The First Expansion (1973) added the United Kingdom (UK), Denmark, and Ireland; the Second added Greece (1981), Spain (1986) and Portugal (1986), and the Third (1995) added Sweden, Finland and Austria. The first wave countries and Greece were given a five-year period to reduce their trade barriers, and the second wave countries were given seven years to dismantle their trade barriers. The Single Europe Act of 1986 set out a program for deeper integration within the Community through removal of non-tariff barriers, free movement of persons and factors of production, and harmonization of standards and other

\footnotetext{
${ }^{5}$ See Swann (1990) for a thorough historical account of the formation of the EU.

${ }^{6}$ See Preston (1997) for a detailed account.
} 
measures, by the end of $1992 .{ }^{7}$ It is after this event that the term 'European Union' (EU) became commonly used to refer to the Community. We will generally use the term EU in this paper, except when referring to earlier historical periods.

\subsection{EFTA}

Shortly after its formation, the EEC entered into talks with a group of countries interested in integration, but reluctant to agree to the sacrifice of independence required by a customs union. The countries involved were the UK, Norway, Sweden, Denmark, Austria, Portugal, and Switzerland. In 1959, after failing to find agreement with the EEC, they began talks on an integration scheme of their own, and in 1960 signed the agreement that established the European Free Trade Association (EFTA) (Preston, 1997, pp. 25-7). Tariff reduction was completed at the end of 1966 . The agreement made no attempt to unify external tariffs, and for the most part omitted agriculture. Finland signed an association agreement with EFTA in 1961 and became a full member in 1986. Iceland joined in 1970 and Liechtenstein in $1991 .^{8}$

In 1972 a free trade agreement was signed between EFTA and the EC, which over five years removed tariffs on industrial goods between the two blocs, but did not touch the many substantial non-tariff barriers that remained.

The UK, Denmark, and Portugal withdrew from EFTA when they signed agreements to join the EC. In 1995, Sweden, Finland, and Austria withdrew from EFTA to join the EU. The current membership of EFTA is Iceland, Liechtenstein, Norway, and Switzerland.

\footnotetext{
${ }^{7}$ See Tsoukalis (1993, ch.3).

${ }^{8}$ European Free Trade Association (1961-1968).
} 


\subsection{MERCOSUR}

Between 1984 and 1989, Argentina and Brazil signed 24 bilateral agreements and in 1990 decided to form a bilateral common market at the end of the year. In mid-1990, Paraguay and Uruguay expressed their desire to integrate with Argentina and Brazil because of their large volume of trade with the two. The result of these discussions was the treaty of Asuncion, which created MERCOSUR. The agreement was signed in March 1991 but did not come into effect until November, when the agreement of Economic Cooperation was signed. ${ }^{9}$

Before 1995, the MERCOSUR area was a free trade zone. The agreement became a customs union on January 1, 1995 - intra-bloc tariffs were eliminated and a common external tariff was instituted (there are, however, a number of exceptions to the common external tariff). This customs union is scheduled to come into full effect on January 1, 2006.

\subsection{NAFTA}

Talks to establish a free trade agreement between Canada and the United States began in 1986. Canada and the United States signed an agreement in 1988, which formed a free trade area in 1989. The auto agreement (1965), which established an integrated market in autos and auto parts between the two countries, preceded the Canada-U.S. free trade agreement by nearly 25 years.

NAFTA negotiations were concluded in 1992 and Mexico acceded to the union in 1994. Several smaller agreements between the U.S. and Mexico (1985, 1987, 1989) preceded their union. In addition, the Maquiladora program (1965) led to increased integration between the two economies. ${ }^{10}$

\footnotetext{
${ }^{9}$ See Noguès and Quintanilla (1993) for a fuller account.

${ }^{10}$ See Hufbauer and Schott (1993) for more details.
} 


\section{Trade shares in the EU, EFTA, MERCOSUR, and NAFTA}

To study the effects of these agreements, it is useful to have a measure of country $i$ 's trade orientation toward a particular bloc. The most obvious such measure is the share of its trade accounted for by member countries $j$. This is denoted $t r_{i, j}^{s}$, and defined by:

$$
t r_{i, j}^{s}=\frac{\operatorname{trade}_{i, j}^{s}}{\operatorname{trade}_{i, w o r l d}^{s}}
$$

where $\operatorname{trade}_{i, j}^{s}$ denotes $i$ 's imports from $j$ plus $i$ 's exports to $j$ at time $s ; \operatorname{tr}_{i, w o r l d}^{s}$ is total trade between $i$ and the world at time $s$; and time $s$ is counted relative to the accession date. Trade shares are constructed from the f.o.b. bilateral trade data recorded in the IMF Direction of Trade Statistics. Trade shares in Europe ${ }^{11}$ ranged from under $10 \%$ to $50 \%$ before accession, and from $25 \%$ to nearly $70 \%$ after accession. Trade shares in MERCOSUR ranged from $5 \%$ to about $45 \%$ and now range from $15 \%$ to $45 \%$. EFTA trade shares range from $10 \%$ to $50 \%$ throughout the relevant years. Finally, NAFTA trade shares range from $20 \%$ to more than $80 \%$.

To help visualize similarities among the unions, the top panels in Figures 1-4 show the median intra-bloc trade share for countries in the EU, EFTA, MERCOSUR, and NAFTA by date relative to date of accession. ${ }^{12}$ They tells us how trade shares look for a typical member of the union. For example, Figure 1 shows that fifteen years after accession, the median share of total trade with the EU countries among the core members was on average 45 percent, about 20 percentage points above the accession date trade share.

The central argument of the paper is evident from these figures. An 'S'-shape with an initial steady state intra-bloc trade share below the accession date trade share, followed by an increase in

\footnotetext{
${ }^{11}$ For the purposes of computing trade shares, for the original members of a union, we define the union, $j$, as the other founders; for subsequent joiners, we define the union as the incumbent members at the time it joins.

${ }^{12}$ NAFTA is not included because there are only three members and the union was formed in two phases.
} 
trade share and eventually flattening out at a new higher level, is a distinct pattern in the European Union. Joining a union clearly affects trade patterns! MERCOSUR and NAFTA now appear to be at the beginning of the 'S', with the share of intra-regional trade expanding. The pattern for EFTA is different from the others because of the circumstances of history. The average intra-regional trade share decreased before the union was formed and then trade shares expanded until several members withdrew, at which point trade shares reversed.

Next, we calculate trade intensity indices for each country. ${ }^{13}$ Trade intensity indices are to some extent better measures of trade reorientation because they control for the overall growth in members' trade relative to world trade. ${ }^{14}$ The trade intensity index for country $i$ with a group of countries $j$ is defined as:

$$
I_{i j}^{s}=\frac{t r_{i j}^{s}}{\frac{\operatorname{trade}_{j}^{s}-\text { trade }_{i, j}^{s}}{\text { trade }_{\text {world }}^{s}}},
$$

where the numerator is the trade share defined above, and the denominator is the sum of the other union members' trade with the rest of the world relative to world trade. The trade intensity index describes how much one country trades with the other members of the union relative to how much the other members trade with the rest of the world. A trade intensity index of unity implies that $i$ 's share of trade with the other union members is identical to the union members' share of trade with the rest of the world. With constant income elasticity of trade across countries, a trade intensity index will not increase as a result of regional income growth. That is, if the members expand trade with each other as a result of relatively high income growth, this will not alter the intensity index because the members' share of $i$ 's trade increases in exactly the same proportion as the other members' share of world trade. The lower panels in Figures 1-4 show median trade

\footnotetext{
${ }^{13}$ See Anderson and Norheim (1993) for a detailed description of trade intensity indices.

${ }^{14}$ In addition, trade intensity indices effectively control for the number of members in the union that the country is joining by controlling for the size of the block.
} 
intensity indices for the EU, EFTA, MERCOSUR, and NAFTA. As seen from these figures, in the trade blocs in question, the movements of trade intensity indices over time are similar to those of trade shares, suggesting the trade growth is not a result of income growth.

Two points emerge from these figures. First, there is an abundance of preaccession adjustment. Second, the adjustment after accession in each case tends to be continuous and decelerating. Both observations suggest an important role for sunk adjustment costs. This will be discussed more fully below.

\subsection{A note on this approach}

Before proceeding to a statistical analysis, it may be worth addressing possible concerns about the usefulness of trade share and intensity measures for the purpose at hand. First, a natural question would be, since the story we have in mind is one of investment, why not look directly at investment data in order to test it? The answer is, first of all, that the question is not so much the quantity of investment occurring but rather the kind of investment. In a country that is expected to join a trade bloc soon, anticipatory investment could simply take the form of a diversion of existing capacity expansion plans away from projects geared at the domestic market or a third-country export market, and toward the bloc market. That would by no means imply any movement in aggregate fixed capital formation, or even in foreign direct investment. However, it would be likely to show up in a reorientation of trade flows. In addition, many of the forms of investment in question would never enter into national accounts data as investment. An example is research on consumer tastes and regulation in the new market. The expenses involved could be considerable, particularly for a small business, but would take the form of travel, consultant and legal fees, diversion of managerial effort, and the like, which would be unlikely to be included as investment in government statistics (see Section 5 for a number of examples and anecdotal support 
for our interpretation). Thus, a focus on trade orientation is actually likely to offer a much better measure of the kind of effects we seek than investment data per se.

Second, one may wonder about the possibility of measuring trade reorientation by estimating a gravity equation, either studying its residuals or using dummy variables for bloc formation. This type of approach has been used by a large number of authors to identify abnormally high or low bilateral trade flows (Eichengreen and Irwin (1998) are one example out of a large number). We argue that using trade intensity indexes is a way of achieving a similar goal in a more parsimonious way. Note that we are interested here in the dynamics of trade reorientation, rather than cross sectional variation. Since a gravity regression is best at controlling for cross sectional variation (depending as it does on slow-moving variables such as GDP, and the distance between partners, which is of course constant over time), its usefulness would be limited in this context.

Finally, one may ask whether the movements in trade shares and intensities indicated in this section are really the result of bloc formation. Is it possible that, for example, trade was simply becoming more regionally focussed everywhere, so that the upward movements in trade shares in our case studies of block formation had nothing to do with the blocs themselves? Examining trade shares and intensity indices among other countries, we find that the answer appears to be 'No'; bloc formation appears to be the main reason for the rise in trade shares. First, in the top panel in Figure 5, we document the median EU trade intensity index over four European countries that were not members of the EU. We find that trade shares (not shown) and trade intensity indices were essentially flat. This suggests that the regionalization of trade that we document was not a general European experience. Second, we calculate intra-regional trade shares and trade intensity indices for several Asian countries, which are not part of a formal union (the median trade intensity index is shown in the lower panel in Figure 5). Again, there is no discernible upward movement 
in trade shares or intensity indices, suggesting that the pattern of rising trade shares and intensity indices that we isolate is unique to the trade blocs.

Having argued that trade shares and intensities are a useful way of measuring the effects in question, we next move to a more systematic analysis of the data.

\section{Some Quantifications}

\subsection{The European Union}

Here we attempt to quantify the basic features of the adjustment process illustrated above. To organize our thoughts, it is useful to consider two different reasons anticipatory movements may occur. The first is that there is some convexity in the costs of reallocating labor or capital, so that it is inefficient to make the whole adjustment at once. This implies a need to begin preparing for a forthcoming new trade regime well before it actually comes into force. The second is a strategic motive. In oligopolistic markets, if there are consumer switching costs, the possibility of erecting entry barriers, or other reasons for a first-mover advantage, then when a new market appears likely to become profitable in the future, a game of preemptive entry arises, in which each competitor attempts to get a jump on the competition. This typically will involve entering the new market before it is actually profitable. To show how these two motives can affect aggregate dynamics, two simple general equilibrium models of trade bloc formation are developed in the Appendix, the first a variant of a Mussa (1978) model and the second a model with a continuum of oligopolistic industries. In both cases, the broad outlines of the aggregate adjustments are similar. The bloc's share of the joining country's trade begins to rise before the trade agreement comes into force, because of anticipatory investment. Its direction of movement is upward overall, and it is continuous except at the actual accession date, on which it jumps up because of a discontinuous 
movement in trade impediments, and hence in prices, on that date. Finally, this adjustment is slower at its beginning and end than in between.

These simple stories suggest four things to look for in characterizing the adjustment process: The size of the adjustment; the typical time of beginning of the adjustment; the typical length of adjustment; and any evidence of a jump, or a particularly large adjustment, at the actual date of accession. To address the first three parsimoniously, we fit a simple piecewise linear adjustment path, and then to address the forth, we estimate time dummies, much in the spirit of Jacobson, Lalonde, and Topel (1994). We focus here on the EU because it offers the most complete accession history, but we will discuss the other blocs briefly as well.

\subsubsection{The piecewise linear approach.}

The first specification assumes that a country's trade share with other union members is constant until $s_{0}$ years before accession, at which point it starts expanding, until it reaches a new higher steady state:

$$
t r_{i j}=\alpha_{i}+\beta_{1} \cdot D_{1} \cdot\left(s-s_{0}\right)+\beta_{1} \cdot D_{2} \cdot\left(s_{1}-s_{0}\right),
$$

where,

$$
\begin{aligned}
& D_{1}=1 \text { if } s_{0} \leq s \leq s_{1}, \text { and } \\
& D_{2}=1 \text { if } s>s_{1} .
\end{aligned}
$$

The dependent variable is the trade share or the trade intensity index between a country $i$ and the other union members $j$. The parameters $s_{0}$ and $s_{1}$ are the turning points or "knots" that we estimate; specifically, $s_{0}$ is the turning point at which trade starts increasing, $s_{1}$ is the turning point at which the new steady state is reached, and $s$ is time, defined relative to the accession date. 
We estimate the $\alpha_{i}{ }^{\prime} s, s_{0}, s_{1}$ and $\beta_{1}$ using non-linear least squares. ${ }^{15}$ This allows us to distinguish between various possible outcomes: (i) an instantaneous adjustment $\left(s_{0}+1=s_{1}\right)$; (ii) a rising trend in the trade share, independent of the trade agreement $\left(s_{0}\right.$ negative and large and $s_{1}$ positive and large; (iii) a delayed adjustment $\left(0<s_{0}<s_{1}\right)$; and (iv) anticipatory adjustment $\left(s_{0}<-1\right)$. It also allows us to measure the length $\left(s_{1}-s_{0}\right)$ and size $\beta_{1}\left(s_{1}-s_{0}\right)$ of the adjustment.

The results are reported in the first two columns of Table $1 .{ }^{16}$ The rejection of (i), (ii), and (iii) is evident. The results suggest that the trade shares and trade intensity indices started expanding around 3 or 4 years before a country joined the union. The estimates of the initial turning points are significantly earlier than the accession date. ${ }^{17}$ About 8 or 9 years after accession, the growth in intra-regional trade was completed, implying that the process took a total of about 12 or 13 years. Finally, the implied rise in the trade share is eighteen percentage points, a third of it occurring before accession.

The final three columns of Table 1 report estimates of timing for each group of joiners separately. Again for each group, we estimate that trade shares started increasing before the agreement was enacted.

\footnotetext{
${ }^{15}$ Specifically, we use the multivariate secant method because the derivatives are not defined. The multivariate secant method estimates the derivatives from the history of iterations. The disadvantage of this approach is that we may converge to a local minimum. However, since our primary concern is estimating the turning points, and the general location of them is near zero, we try several starting points between -5 and 3 to ensure that we find the best fit. Convergence always occurred at points significantly less than zero.

${ }^{16}$ Data on trade shares and trade intensity indices used in the regression are from 1948 to 1995 . We also try truncated the data to include on data between 25 years before and after accession. The results were very similar.

${ }^{17}$ We also estimate a modified logistic (not reported), which gives similar results for the turning points; and a standard logistic function (also not reported), which suggests that one-quarter of the adjustment was achieved before accession.
} 


\subsubsection{The time dummy approach.}

The second specification does not impose a functional form for the adjustment path, but rather estimates year effects for both calender time and time relative to accession date. In addition, we include four countries-Switzerland, Finland, Sweden, and Norway-that were not EU members in the period studied in order to get a better estimate of macro effects. ${ }^{18}$ Specifically, the regression equation is:

$$
t r_{i j}^{t}=\gamma_{t}+\alpha_{i}+\sum_{s \geq-5}^{15} \beta_{s} D_{i t}^{s}+\varepsilon_{i t}
$$

where the $\gamma_{t}$ are calendar-time fixed effects; the $\alpha_{i}$ are country fixed effects; $\beta_{s}$ are fixed effects for the year relative to accession date; and $D_{i t}^{s}$ is a dummy variable that is one if, in year $t$, country $i$ had acceded to the union $s$ years earlier. We allow accession effects to appear five years before date of entry, i.e. there is a separate time dummy for each year between -5 and 15 . The time dummy for the 15 th year is one if $s \geq 15$. Thus, the $\beta_{s}$ can be interpreted as the effect of the agreement $s$ years after accession or $-s$ years before, relative to the status quo ex ante (here implicitly defined as more than 6 years before accession). We use FGLS with fixed effects and a correction for autocorrelation (Beach and McKinnon 1978). We assume the error is uncorrelated across countries. The results are plotted in Figure 6, and Table 2 reports the coefficients and t-statistics for the anticipatory effects. ${ }^{19}$ The results confirm our earlier estimates, suggesting that a significant portion of the adjustment in trade share occurred before the year of accession.

All of the coefficients on the years prior to accession are positive, and their magnitude and significance tend to increase as $s$ approaches zero. The coefficients on pre-accession effects for

\footnotetext{
${ }^{18}$ For example, EU trade shares are likely to decline during the oil crisis, because a larger nominal value was spent on external imports. We also estimated the equation without the four additional countries and the results were similar.

${ }^{19}$ We also included country specific time trends (not reported). The results were very similar.
} 
trade shares are significantly different from zero in three out of five years. However, the coefficients on pre-accession effects for trade intensity indices are not significantly different from zero, and tests of the hypothesis that the sum of the preaccession coefficients is zero are not rejected at the 5 percent level (Table 3). Thus, this time dummy specification provides significant evidence for the preaccession effects in trade shares and only modest evidence for the preaccession effects in trade intensity indices. One difficulty is that the bunching of accessions to the EC makes the substantial preaccession movements seen above difficult to distinguish decisively, through purely statistical means, from calendar-year effects. Recall that the twelve members considered have joined in three synchronized waves, making the statistical distinction between calendar year effects and year-relative-to-accession effects naturally difficult. Indeed, estimating equation 4.1 without the calendar year effects provides strong evidence of preaccession adjustment in both trade shares and trade intensity indices (Table 2, last two columns). Preaccession effects are significant prior to accession and are increasing as accession approaches. Moreover, if we use a European GNP index as a measure of macro-effects, instead of calendar year dummies, the preaccession effects (not reported) are significant for both trade shares and intensity indices and are very similar to the effects reported excluding the time dummies.

Next, we go through the same exercise in first differences, in order to look for a particularly strong movement in the accession year. Here, the first difference of the trade share or intensity index is regressed on calendar-year and year-relative-to-accession time dummies. Figure 7 shows the estimates of the annual change in year fixed effects for trade shares. As suggested by theory, the adjustment is generally more rapid in the middle of the process than at the ends, and one of the largest single-year adjustments appears in the year of accession. ${ }^{20}$ Using the estimates from

\footnotetext{
${ }^{20}$ The interpretation is complicated by gradualism in post-accession trade policies. The original members removed tariffs over a period of ten years; Denmark, Ireland, the U.K. and Greece, five years; Spain and Portugal, seven
} 
the regression equation 4.1 and the results from first differences, we test the hypothesis that the change in trade shares in that year is equal to the average change in trade, reporting the significance level of the appropriate Wald statistic from the levels regression and the first-difference regression respectively in the last two lines of Table 3. It is rejected at the 1-percent and 10-percent level, respectively, for the version in shares, and 2- and 10-percent, respectively, for intensities.

In short, although what can be done through statistical methods is limited due to the small number of events involved, the EU experience does offer evidence of preaccession adjustment; accelerating and then decelerating adjustment; and a jump in the accession year. All of this is consistent with elementary adjustment cost models.

\subsection{The other trade blocs}

In treating EFTA, we need to make allowance for the temporary nature of many of its members. Accordingly, we estimate a different piecewise linear shape for the adjustment process:

$$
t r_{i j}=\alpha_{i}+\beta_{1} \cdot D_{1} \cdot\left(s-s_{0}\right)+\beta_{1} \cdot D_{2} \cdot\left(s_{1}-s_{0}\right)+\beta_{2} \cdot D_{2} \cdot\left(s_{1}-s\right) .
$$

In other words, we allow for a period of decline after the initial increase. The results are reported in Table $4 .^{21}$ Again the estimate of the first turning point, $s_{0}$, for both share and inten is less than zero, though neither is significantly different from zero.

In addition, the year-fixed-effect regression was performed, without the calendar-year effects because too many countries joined simultaneously for time effects to be identified separately. ${ }^{22}$ To years. During the transition all forms of protection were removed including quotas, tariffs, and all other protective measures. (Swann 1990, p. 88). Nonetheless, in each case, a substantial reduction in trade barriers occurred on the date of accession.

${ }^{21}$ Data are from 1953-1995.

${ }^{22}$ Finland technically joined in 1986 , but is treated here as part of the original group because with its association agreement of 1961 it had such a close relationship with the others as to be effectively a full member from that date 
control for non-accession related movements over time, we included country-specific time trends. The results are reported in Figure 8 and Table 5. Both approaches show large effects of the agreement, with the rise in trade share implied by Table 4 equal to six percentage points, spread over ten years. Table 6 reports results of the hypothesis tests that there was no preaccession adjustment, and that the jump in the first year is equal to the average jump, for trade shares and trade intensity indices. There is little evidence of increased adjustment in the first year. Tariffs in the EFTA region were removed at a steady rate over a six year period. An acceleration of adjustment during this period is noticeable, followed by slower adjustment over the next five years. $^{23}$

For this trade bloc, preaccession adjustments are either very weak or absent, the strongest evidence of anticipatory effects being the jump in trade intensity index one year before the agreement took effect, as recorded in Table 5. This contrast with the EU case is consistent with the historical record, since EFTA was formed, almost as an afterthought, after the failure of talks in 1959 to incorporate the countries involved into the EC framework (Preston, 1997, p. 26). The EFTA negotiations were concluded the following year, so there was very little time for anticipation of the new bloc to develop.

(EFTA 1962). The only other later joiners were Lichtenstein (1991), for which the analogous data are unavailable, and Iceland (1970), which we exclude because of its highly anomolous trade behaviour and consequent noise in its trade data. Three quarters of Icelandic exports take the form of fish, and the catch is subject to extreme variations for ecological reasons. In the late 1960's, for example, the herring catch dropped by over 90 per cent, and partly in consequence, its exports to EFTA countries saw some sharp declines around its accession date. Clearly, this has nothing to do with the effect of the trade block. See EFTA(1972, p.14), and EFTA(1970, p.25).

${ }^{23}$ Tariffs in the EFTA were undone in a period of six years, 20 percent in the first year, followed by 10 percent annual installments, with a final reduction of 20 percent at the end of the sixth year, explaining the big jump in the following year. Originally tariffs were to be reduced over a nine year period, but in part to beat the EU in becoming the first tariff free zone the pace of tariff reduction was accelerated. (See the EFTA, various years 1961-1968.) 
For MERCOSUR and NAFTA, we use a slightly different adjustment shape, because the process is still very much ongoing in these blocs. The form we impose is:

$$
t r_{i j}=\alpha_{i}+\beta_{1} \cdot D_{1} \cdot\left(\text { year }-s_{0}\right)
$$

and the results are in Table $4 .{ }^{24}$ The adjustment in MERCOSUR appears to have begun about 3 years in advance of the agreement. In the case of NAFTA, the adjustment begins twelve years in advance in shares, and in intensities, the adjustment appears to have been continuing at an even pace since the beginning of the data set (see Figure 4). For this reason, estimating equation 4.3 effectively reduces to the case $s_{0}=-\infty, s_{1}=\infty$. In sum, although MERCOSUR looks qualitatively much like a version of the EU 'S' pattern in progress, NAFTA looks like a case in which an ongoing shift in comparative advantage may have induced the agreement as easily as the other way around.

\section{Interpretation: Is this Anticipatory Behavior?}

Part of our interest in studying these trade flow dynamics has been to provide evidence that anticipatory investment has been important in shaping the adjustments to trade agreements. This is a natural interpretation of the fact that the trade adjustment has often appeared to begin before the actual accession occurred. However, since there are other possible interpretations available, in this section we put forward a case for the anticipatory interpretation. Note that we do not claim that all of the preaccession movements we observe are due to anticipatory investment, but we argue that it is implausible to deny that at least a large portion of it is. In turn, we will (i) argue that the preconditions for anticipatory investment are present; (ii) point to aggregate and anecdotal

\footnotetext{
${ }^{24}$ For NAFTA the data used are from 33 years before accession, i.e. 1956 for Canada and the United States and 1961 for Mexico, through 1995. For Mercosur the data are from 1965 to 1995. The results are robust to shortening the sample period.
} 
evidence on investment flows; and (iii) discuss the two main alternative candidate explanations for the preaccession movements.

(i) Preconditions. For anticipatory investment to occur in response to a forthcoming change in trade regime, there are two key requirements. First, there must be a need for sunk sectoror destination-specific costs to be incurred as part of the adjustment to the change; and second, business people must expect a significant effects on the business environment due to the forthcoming change. Both of these conditions are typically satisfied in the case of a country joining a trade bloc.

As illustrated in the appendix, the sunk costs in question can take a variety of forms, including construction of marketing channels in the destination market where sales are expected to expand; retraining or retooling costs of intersectoral reallocation; product redesign to meet local tastes or regulations, and the like. That such costs are a routine part of everyday international business is well documented. Business manuals such as Axtell (1989) provide long lists of adjustments that must be made in approaching a new market; the need to conduct substantial legal research in order to export successfully even from Canada to the United States is well known. ${ }^{25}$ The consequences of such sunk costs can be seen in export data from Colombia (Roberts and Tybout, 1997), where hysteresis effects of past exporting are very clear in firm-level data.

Second, lest it be suspected that business people take all talk of future trade agreements as irrelevant, either because of doubts about ratification or because they regard trade agreements as having a minimal real effect on their business environment, there are various forms of evidence that they can have substantial effects on business expectations. In the case of the Canada-U.S. Free Trade Agreement of 1988, Thompson (1993) shows that the successful conclusion of the talks just

\footnotetext{
${ }^{25}$ See Graham (1987). The early days of the CUFTA saw a surge in demand for lawyers by firms preparing to do business across the border for the first time (Christian Science Monitor, Tuesday, February 13, 1990, p.8; Jenish (1988a, p.33)).
} 
before the midnight deadline had a dramatic effect on Canadian stock market prices, indicating that profits in some sectors were expected to rise dramatically and some to fall dramatically as a result of the agreement. This occurred despite the considerable remaining uncertainty over the ratification. Thompson (1994) demonstrates even stronger announcement effects after conditioning on firm characteristics. Between negotiation and ratification of the NAFTA, the Mexican stock market reacted sharply to any news affecting the probability of ratification (Economist, August 14, 1993, p. 78). Surveys conducted by the European Commission while the completion of the internal market was being negotiated indicated that a large fraction of European businesses expected 1992 to have a large effect on their business environment and strategies, citing increases in expected investment in their home markets as well as in other member countries (Commission of the EC (1989)). Some additional examples are offered under section (ii) below.

Thus, since sunk costs are typically needed for adjustment, and some substantial change in the business environment is typically anticipated due to an upcoming trade agreement, it would seem to be surprising if there were not some signs of anticipatory investment in the data.

(ii) Aggregate and anecdotal investment evidence. Apparent anticipatory effects have shown up in aggregate data on investment flows just prior to major trade agreements. For example, after controlling for changes in investment law in 1989, Stevens (1996) finds evidence of a break in the behavior of US Foreign Direct Investment (FDI) into Mexico after 1992, the year in which NAFTA was signed. The agreement, however, did not go into effect until 1994. He interprets this as evidence of anticipatory behavior. Aristotelous and Fountas (1996) investigate the determinants of FDI into the EU. They find evidence of a single-market effect: U.S. and Japanese FDI flows increased in anticipation of a larger market. Similar observations are found in Commission of the EC (1989).

Further, it is easy to find individual cases in which a particular investment has been made 
explicitly because of an upcoming trade agreement. In the case of the Canada-U.S. free trade agreement, a vice-president of Vineland Estate Wines in Ontario explained to a reporter in 1988 that he had launched an extensive sales campaign in the United States to line up customers in preparation for the as-yet-unratified agreement (Jenish 1988a, p.32). The Chairman of Canada's largest brewery, Labatts, explained that the company had seen free trade with the US as inevitable as early as four years earlier, and had launched a major acquisition campaign in the US to be ready for it. As a result, by the time the agreement was actually completed, forty percent of the company's revenues were derived from American sales (Jenish 1988b, p.38).

Turning to European examples, in 1982 Samsung Electronics chose Portugal as the site of its first European manufacturing facility, partly because of the anticipated accession to the EC (Financial Times, Wednesday, March 31, 1982, Section I, p.6). The project was an $\$ 8.7$ million color television plant. An interesting note is that part of the motivation for an early investment in that case was the expected time lag before enough of the value-added could be produced in Portugal to qualify as an EEC-produced good, instead of a Korean good. Another example is the Portuguese textile sector, which by 1983 had already spent a great deal of money upgrading its equipment and technology specifically to prepare for the accession (Financial Times, Wednesday, September14, 1983, Section IV, p. VI). As summarized by one textile manager, "We told ourselves that if we were to join in 1984 then we needed to have completed all our capital spending by 1982. This would allow us two years in which to buildup our cash flow. We are on target." Of course, the diplomats were themselves not on target, and as it turns out, the accession agreement was delayed two more years beyond that.

A final example is from Spain. As early as 1979, a surge of foreign direct investment poured in to the country explicitly to take advantage of the forthcoming Spanish accession, which was 
then widely expected to occur around 1983 (New York Times, Monday, July 9, 1979, Section 4, p. 1). The investments spanned manufacturing and banking, but the most spectacular was General Motor's $\$ 1.58$ billion Opel plant, GM's largest overseas investment, which subsequently developed into one of the major suppliers of small cars for all of Europe.

Thus, there is no shortage of anecdotal evidence to support the existence of anticipatory investment, exactly along the lines we have been suggesting.

(iii) Alternative interpretations. To give skepticism its full play, we look here at two alternative explanations for the preaccession adjustments observed in the data. The first is 'reverse causation,' and the second is a 'stepping-stone argument,' that large trade agreements are preceded by smaller ones.

Under the reverse causation interpretation, in forming trade agreements, countries team up with the countries with whom they most tend to trade, seeking 'natural trade partners' as bloc partners. Over time, as comparative advantage shifts, a country may happen to acquire a new natural trading partner; accordingly, trade with that country will grow relative to trade with others, and in time they may form a free trade area in consequence. This could, in principle, explain the timing we see in the data without any recourse to anticipatory investment. ${ }^{26}$

This has a certain broad plausibility, since the choice of trade partners and the timing of agreements are likely to respond to comparative advantage. In particular, the CUFTA may have been formed in exactly this way. The US share of Canada's imports and exports grew steadily over this century to a quite dominant position, and despite the efforts of the Canadian government in the 1970s, it continued to grow. Finally, despite a long-standing taboo on the subject in Canadian

\footnotetext{
${ }^{26}$ Bhagwati and Panagariya (1996) have argued that even if a trade relationship is "natural" it does not justify preferential treatment. Moreover, since comparative advantage changes over time, "natural partners" can become "unnateral partners", making an initially trade creating union, trade diverting.
} 
politics, Canada's trade dependence on the US reached the stage at which a trade agreement began to appear almost inevitable, and was indeed signed in 1987. (See Winham, 1988.) Thus, at least a significant portion of the preaccession trade share movement in the North American case could be interpreted as a case of reverse causation.

However, there are other examples in which it could not possibly have any part in the explanation. The second expansion of the EC is a good example. The governments of Spain and Portugal (joining in 1986), had long been interested in joining, but had been prevented from applying by EC rulings requiring an end to dictatorship as a precondition. With the death of Franco in 1975, the 1974 coup overthrowing the dictatorship in Portugal, and the subsequent reestablishment of democracy in these countries, suddenly the potential new members were eligible. ${ }^{27}$ Negotiations followed soon afterward.

Since it would seem preposterous to argue that the fall of the dictatorships was in any way caused by a shift in comparative advantage, the timing of the start of negotiations can thus be safely thought of as economically exogenous for our purposes. Further, as Figure 1 shows, preaccession adjustment is extremely pronounced for second expansion. Thus, this episode would appear to rule out reverse causation as the sole cause of the preaccession movements seen in the data.

Under the stepping stone interpretation, whenever a major trade agreement is concluded, it has been preceded by a number of smaller ones between the parties involved, and the preaccession reorientation of trade is simply a result of those. This was suggested by Wonnacott (1998) in comments on the interpretation some of Eichengreen and Irwin's (1998) regressions. The regressions in question showed that a dummy variable for regional trade agreements had a positive effect on trade flows between member countries, even in years before the agreement came into effect. Thus, in Wonnacott's interpretation, the positive coefficient on the EEC dummy in years prior to the EEC

\footnotetext{
${ }^{27}$ See Story (1986) and Preston (1997, ch. 4).
} 
may reflect the ECSC. In our data, this is a particularly relevant consideration for MERCOSUR, since that pact resulted in 1991 from a complicated and gradual succession of bilateral agreements in the immediately preceding years - see section 2.3 .

However, once again, the example of the second expansion of the EC shows that this cannot be the entire story. It is true that both Spain and Portugal had earlier agreements with the EC before joining the community, but in order for those agreements to be the cause of the preaccession movements in the data, their timing is completely wrong. Spain had a more modest agreement with the EC, dating back to 1970. This had provided for partial mutual tariff reductions phased in until 1977, but the process was brought to a halt by discord in 1975 and then supplanted by the accession talks (see Preston (1997, p. 64)). Portugal's Association Agreement also had 1977 as the target date for most of its tariff reductions (Preston, 1997, p. 65). In addition, the subsequent accession negotiations were remarkably difficult and fractious, and produced no intermediate agreements; ${ }^{28}$ after eight years of negotiation, one single, mammoth treaty was signed by Spain and another by Portugal in December 1985. Thus, the surge in Iberian trade orientation toward the EC in the early 1980s simply cannot be explained through stepping stone agreements.

Thus, although the two alternative explanations discussed here undoubtedly have some role in explaining preaccession reorientations, they can by no means account for all of them. There appears to be a considerable role for anticipatory investment.

The case set out here is of course not a proof of the role of anticipatory investment in the observed preaccession movements, but we hope that the presence of the necessary preconditions,

\footnotetext{
${ }^{28} \mathrm{~A}$ partial exception is the EC commitment to structural adjustment funds to Portugal in preparation for accession. Some of these funds were disbursed in the early 1980s, but this was mainly for infrastructural development such as airport improvement, and thus not particularly biased toward increased Portugal-EC trade any more than trade with any other trade partner. See Financial Times (London), Wednesday, December 21, 1983, Section I, p. 2.
} 
the abundance of anecdotal evidence, and the existence of cases unexplainable by the two most natural alternatives, are together persuasive.

\section{Conclusion}

We have attempted to achieve three very limited objectives. First, we have tried to show that when an economy joins a trade bloc it tends to exhibit dynamics that are consistent with standard economic models of investment and adjustment cost, and thus to reemphasize the importance of such costs in analyzing trade policy. In particular, the pattern of a rough 'S' shape, with an accelerating and then decelerating adjustment, and a jump on the date of discrete changes in tariffs, appears to be a good description of how trade orientation moves. Second, we have attempted to quantify these dynamics. We hope that the ballpark figure of a twelve-year adjustment in the case of the EU will enable a modest refinement of guesses as to how long it takes for the long-run effects of a trade agreement to arrive. At any rate, even in discussing non-European economies, a guess based on European data is likely to be an improvement on guesses based on no data at all. Finally, we have made an effort to convince the reader that anticipatory investment induced by a forthcoming change in trade policy regime not only has theoretical or anecdotal validity, but is also clearly evident in the aggregate behavior of open economies. 


\section{References}

[1] Anderson, Kym and Hege Norheim (1993). "History, Geography and Regional Integration," CEPR Discussion Paper No. 795.

[2] Aristotelous, Kyriacos, and Fountas Stilianos (1996). "An Empirical Analysis of Inward Foreign Direct Investment Flows in the EU with Emphasis on the Market Enlargement Hypothesis," Journal of Common Market Studies, December pp. 571-583.

[3] Axtell, Roger E. (1989). The Dos and Taboos of International Trade: A Small Business Primer, New York: Wiley.

[4] Bhagwati, Jagdish and Arvind Panagariya (1996). "Preferential Trading Areas and Multilateralism: Strangers, Friends, or Foes?" In Jagdish Bhagwati and Arvind Panagariya (ed.) The Economics of Preferential Trade Agreements, American Enterprise Institute Press.

[5] Commission of the EC (1989). "Facing the Challenges of the Early 1990s," European Economy 42, November.

[6] Deardorff (1998). "Determinants of Bilateral Trade: Does Gravity Work in a Neoclassical World," in Jeffrey A. Frankel (ed.), The Regionalization of the World Economy, University of Chicago Press.

[7] Dehejia, V. H. (1995). "Will Gradualism Work When Shock Therapy Doesn’t?" CTPL Occasional Paper No. 35, Centre for Trade Policy and Law, Ottawa, Canada.

[8] European Free Trade Association. Annual Report of the European Free Trade Association, Geneva, various years 1961-1991. 
[9] Eichengreen, Barry, and Douglas A. Irwin (1998). "The Role of History in Trade Flows," in Jeffrey A. Frankel (ed.), The Regionalization of the World Economy, University of Chicago Press.

[10] Frankel, Jeffrey A. (1997). Regional Trading Blocs in the World Economic System, Institute for International Economics, Washington D.C..

[11] Freund, Caroline (1998). "Regionalism and Permanent Diversion," International Finance Discussion Papers Number 602, Board of Governors of the Federal Reserve System, Washington, D.C.

[12] Fudenberg , D. and J. Tirole (1987). "Understanding Rent Dissipation: On the Use of Game Theory in Industrial Organization," American Economic Review: Papers and Proceedings 77: pp. $176-83$.

[13] Graham, Thomas R. (1987). "Knowing United States Trade Laws," Canadian Business Review (August), pp. 39-41.

[14] Hufbauer, Gary and Jeffrey Schott (1993). NAFTA: An Assessment. Washington, DC: Institute for International Economics.

[15] Jacobson, Louis S., Robert J. LaLonde, and Daniel Sullivan (1993). "Earnings Losses of Displaced Workers," American Economic Review, Vol. 83, No.4, pp. 685-711.

[16] Jenish, D’Arcy (1988a). "Winning the Trade Battle," Macleans, September 19, 1988, pp. 324. (1988b).

[17] _--_.. "The Canadians Look South: A Race to Invest in America," Macleans, September 19, 1988, pp. 38-40. 
[18] Levy, Santiago, and Sweder van Wijnbergen (1994). "Labor markets, migration and welfare: agriculture in the North-American Free Trade Agreement," Journal of Development Economics 43 (April), pp. 263-78.

[19] Maggi, Giovanni, and Andres Rodriguez-Clare (1998). "The Value of Trade Agreements in the Presence of Political Pressures," Journal of Political Economy, forthcoming.

[20] McLaren, John (1997). "Size, Sunk Costs, and Judge Bowker's Objection to Free Trade," American Economic Review, 87:3.

[21] Mussa, Michael (1978). "Dynamic Adjustment in the Heckscher-Ohlin-Samuelson Model," Journal of Political Economy 86:5, pp. 775-91.

[22] Nogués, Julio J. and Rosalinda Quintanilla (1993). "Latin Americas Integration and the Multilateral Trading System," in De Melo, Jaime and Arvind Panagariya (ed.), New Dimensions in Regional Integration. Cambridge: Cambridge University Press.

[23] Preston, Christopher (1997). Enlargement and Integration in the European Union. London: Rutledge.

[24] Roberts, Mark J. and James R. Tybout (1997). "The Decision to Export in Colombia: An Empirical Model of Entry with Sunk Costs," American Economic Review 87:4 (September), pp. 545-64.

[25] Staiger, Robert and Guido Tabellini (1989). "Rules and Discretion in Trade Policy," European Economic Review 33, pp. 1265-77.

[26] Stevens, Guy (1998). "U.S. Direct Investment to Mexico: Politics, Economics, and NAFTA," Contemporary Economic Policy, April, pp. 197-210. 
[27] Story, Jonathan (1986). "The Ten Plus Two: Spain and Portugal Join the EC," SAIS Review.

[28] Swann, Dennis, (1990). The Economics of the Common Market, Penguin Books.

[29] Thompson, Aileen (1993). "The Anticipated Sectoral Adjustment to the Canada-United States Free Trade Agreement: An Event Study Analysis," Canadian Journal of Economics XXVI:2 (May), pp. 253-72.

[30] Thompson, Aileen (1994). "Trade Liberalization, Comparative Advantage, and Scale Economies: Stock Market Evidence from Canada." Journal of International Economics 37:1,2 (August), pp. 1-27.

[31] Tsalicoglou, Iacovos S. (1995). Negotiating for Entry: The Accession of Greece to the European Community. Aldershot, UK: Dartmouth Publishing Co.

[32] Tsoukalis, Loukas (1993). The New European Economy: The Politics and Economics of Integration. Oxford: Oxford University Press.

[33] Winham, Gilbert R. (1988). "Why Canada Acted," in William Diebold Jr. (ed.) Bilateralism, Multilateralism and Canada in U.S. Trade Policy. Cambridge: Ballinger pp. 37-68.

[34] Winters, Alan L. (1984). "British Imports of Manufactures and the Common Market" Oxford Economic Papers 36 pp. 103-118.

[35] Winters, Alan L. (1985). "Separability and the Modelling of International Economic Integration" European Economic Review 27 pp. 335-353.

[36] Wonnacott, Paul (1998). "Comment," in Jeffrey A. Frankel (ed.), The Regionalization of the World Economy, University of Chicago Press. 
[37] Yannopoulos, G. N. (1988). Customs Unions and Trade Conflicts: The Enlargement of the European Community, London: Routledge. 


\section{Appendix: Two Paradigms of Dynamic Adjustment}

Here we show that the essential elements we look for in the data - anticipatory investment, a discontinuity at the accession date, an acceleration followed by a deceleration of adjustment - can be found in models with very different underlying mechanisms. In each case it should be underlined that our goal is to write down the simplest possible example; a more realistic model would take up much more space without adding much more insight.

\subsection{Convex adjustment costs}

Consider the following variant of a Mussa (1978)-style model. Suppose that there are three countries, $X, Y$ and $Z$, and three goods, $x, y$, and $z$. Good $z$ is consumed and produced everywhere, but $\mathrm{x}$ is consumed only in $X, y$ is consumed only in $Y$, and $x$ and $y$ are produced only in $Z$. There is initially an ad valorem tariff of $X$ on imports into country $X$ and $Y$ into country $Y$. No good is storable, and the $X$-country representative agent has a utility function of the form $z+U(x)$ (where $U$ is concave and differentiable), so we may derive an instantaneous demand relation $D_{x}\left(q_{x}(t)\right)$ giving the quantity of $x$ demanded in $X$ at time $t$ as a function of the price, $q_{x}(t)$, of $x$ in $X$ at time $t$. Similarly, we can derive demand $D_{y}\left(q_{y}(t)\right)$ for $y$ in $Y$, and if these are well-behaved, we can then derive the market-clearing relations $P_{x}\left(x(t), \tau_{X}\right)$ giving the price $p_{x}$ of $x$ in $Z$, and $P_{y}\left(y(t), \tau_{Y}\right)$ giving the price of $y .{ }^{29}$ Production of one unit of $x$ or $y$ requires one unit of capital, and production

\footnotetext{
${ }^{29}$ This artificial structure is the simplest possible way of achieving determinate bilateral trade flows in a competitive three-country model; it is well-known that with more work, one can derive bilateral flows in a variant of a HecksherOhlin model (see Deardorff, 1998), and it would thus be straightforward to do what is done here in such a setting as well.
} 
of one unit of $z$ requires one unit of labor. There are a fixed endowment of labor and capital in country $Z$.

Capital is a quasi-fixed factor, meaning that it can be moved from x-production to $\mathrm{y}$-production or vice versa at a cost that depends on the rate at which it is moved. Specifically, denote the rate of change of $x$ output in country $Z$ with respect to time $t$ by $\dot{x} \equiv d x / d t$. This is also equal to the rate at which capital is leaving $\mathrm{x}$ production and entering $y$ production, and thus also equal to minus one times the rate of change of $y$ production. A capital owner wishing to move capital from one good to the other at the rate requires an instantaneous labor input of $\Psi(\dot{x})$, where $\Psi(0)=0$, $\Psi^{\prime}(0)=0$, and $\Psi^{\prime \prime}(0)>0 \forall \dot{x}$.

Take good $z$ in $Z$ to be the numeraire. Given that the wage is then fixed at unity by technology in the $z$ sector, and given an anticipated time path $p_{j}(t)=q_{j}(t) /\left[1+\tau_{j}(t)\right]$ for the $Z$-country price of good $j$, competitive equilibrium in the capitalist sector will maximize:

$$
\int_{t=0}^{\infty} e^{-\rho t}\left[p_{x}(t) x(t)+p_{y}(t)(K-x(t))-\Psi(\dot{x}(t))\right] d t,
$$

where $K$ is the total capital in $Z$ and $\rho$ is the discount rate. Letting $\lambda$ denote the value to a unit of capital producing $x$ instead of $y$, we have the following:

$$
\lambda(t) \equiv \int_{t}^{\infty} e^{-\rho s}\left(p_{x}(s)-p_{y}(s)\right) d s
$$

The first-order condition (by rearrangement of the Hamiltonian) can then be written:

$$
\Psi^{\prime}(\dot{x}(t))=\lambda(t) \forall t
$$

and the rate of change of the value of $\mathrm{x}$-capital is:

$$
\begin{aligned}
\dot{\lambda}(t) & =\rho \lambda(t)-\left(p_{x}(t)-p_{y}(t)\right) \\
& =\rho \lambda(t)-\left[P_{x}\left(x(t), \tau_{X}\right)-P_{y}\left([K-x(t)], \tau_{Y}\right)\right] .
\end{aligned}
$$


These two differential equations can be graphed in the familiar phase diagram form of Figure A1, where the $\dot{\lambda}=0$ locus is indicated; the $\dot{x}=0$ locus is the horizontal axis; their intersection is the steady state point A; and the saddle path is marked as SS. Now, suppose that the system is initially at this steady state, and that at time 0 the governments of $X$ and $Z$ decide to form a free trade area as of time $t^{*}>0$. This will involve an abrupt drop in the tariff $\tau_{X}$ to a value of zero at that moment. This will leave the $\dot{x}=0$ locus unchanged, but will shift the $\dot{\lambda}=0$ locus up abruptly at $t^{*}$, causing the system to jump from A to B at $t=0$ and then follow the indicated north-easterly path until it reaches the new saddle path at exactly $t=t^{*}$, approaching thereafter the new steady state of C.

Since at each point in this process the adjustment path lies above the $\dot{x}=0$ locus, and since $\lambda$ first rises and then falls, capital moves steadily toward $x$ production, first at an accelerating rate, then at a decelerating rate. In other words, if $x(t)$ is plotted against $t$, the result will be an Sshaped figure, with $t^{*}$ located in the interior of the 'S'. Now consider X's share of Z's exports, $\alpha_{X} \equiv$ $p_{x}(t) x(t) /\left[p_{x}(t) x(t)+p_{y}(t) y(t)\right]$. If the demand relations $D_{x}$ and $D_{y}$ are downward-sloping, then $\alpha_{X}(i)$ will begin to adjust to the news of the free trade area at $t=0$; (ii) will adjust continuously, except at $t=t^{*}$, at which point it will jump up discontinuously; ${ }^{30}$ (iii) will take a higher value in the new steady-state than in the original one; ${ }^{31}$ and (iv) will decelerate toward a zero rate of change as the new steady-state is approached. Whether or not it has precisely an 'S'-shape depends on elasticities. $^{32}$

\footnotetext{
${ }^{30}$ This is, of course, because of the removal of the tariff at that date, causing a discontinuous movement in prices. This statement is made in reference to prices net of tariff; measured at tariff-inclusive prices $q_{x}, \alpha_{X}$ would have a continuous path.

${ }^{31}$ Simply, the condition $p_{x}=p_{y}$ must hold at each steady state, so the higher level of $x$ in the new steady-state guarantees a higher value of $\alpha_{X}$.

${ }^{32}$ If the demand relations are elastic everywhere, then $\alpha_{X}$ will rise monotonically. Failing that, then $\alpha_{X}$ may at
} 


\subsection{Strategic preemption}

Now consider the above three-country setup, but with the following production structure. Each country produces an agricultural good, good $y$, each unit of which requires one unit of labor, and which will serve as a numeraire. However, $Z$ also produces a continuum of manufactured goods, indexed by $i \in[0,1]$, each of which is produced by a Cournot duopoly. Because each of these manufactured goods requires a substantial element of costumer service, a firm cannot sell in any country without first establishing a subsidiary (such as a dealership or service center) in that country. This requires a one-time labor input of $F_{i} \in\left[F_{\min }, F_{\max }\right], F_{\max }>F_{\min }>0$. Let the distribution of the $F_{i}$ across industries be given by a density function $f$, and without loss of generality, assume that the goods have been numbered so that $i>j$ implies $F_{i}>F_{j}$. Thus,

for each $i, i=\int_{0}^{F_{i}} f(F) d F$. Having established this subsidiary, it can then ship from its plant in $Z$ to satisfy local demand in the other country; because of large fixed and sunk costs required to establish a plant, it is never worthwhile to produce in more than one location. The marginal cost of production is $c>0$ units of labor for all $\mathrm{i}$.

Both $Y$ and $Z$ are mature economies, in which the Cournot competition results in sales of $\bar{x}$ units of each manufactured good, at a price $\bar{p}$, at each date. The $X$ economy, however, is growing for exogenous reasons, and exhibits a demand curve for good $i$ given by $p_{i}=D\left(x_{i} ; t\right)$, where $p_{i}$ denotes the price of good $i$ in $X ; x_{i}$ denotes the quantity sold there; and t denotes time. The function $D$ is differentiable, decreasing in its first argument and increasing in its second argument. Suppose that all trade is free, except that the $X$ government charges a specific tariff on manufactured imports, which takes a value of $\tau(t)$ at time $t$. Denote the profit an $i$-sector monopolist would make in the $X$ some point drop, and in general $\dot{\alpha}_{X}$ may, in principle, rise and fall several times. Whether or not $\alpha_{X}$ has an exactly 'S'-shaped path is, of course, an empirical matter. 
market, ignoring the sunk cost of the subsidiary, by $\pi^{*}(t, \tau) \equiv \max _{q}\{(D(q ; t)-c-\tau) q\} \forall i$, where $\tau$ is the tariff. The profit-maximizing quantity, $x(t, \tau)($ price, $p(t, \tau))$ is continuously decreasing (increasing) in $\tau$.

There are several ways to introduce a motive for preemptive investment (see Fudenberg and Tirole (1987) for a basic reference). For our purposes, simply presume that the first producer to set up a subsidiary in the $X$ market is able to undertake strategies to make it difficult or unprofitable for the second firm to enter (for example, a small bribe to the bureaucrat responsible for approving inward direct investment). Thus, the first in will be a monopolist forever. Knowing this, if it ever becomes attractive to enter the $X$ market to sell good $i$, the two firms producing good i will play a preemption game.

Suppose that the $X$ tariff initially has a value of $\tau^{1}>0$, and suppose that $\pi^{*}\left(t, \tau^{1}\right)<\rho F_{i}$ $\forall i, \forall t$,so that absent tariff lowering, no firm would create a subsidiary in $X$. Now suppose that at time $0, X$ and $Z$ agree to form a free trade area as of time $t^{*}>0$. This will involve an abrupt drop in the tariff to a value of zero at that moment, but between time 0 and $t^{*}$, the tariff will remain at $t^{1}$. Define the gross value to monopoly in any manufacturing sector in $X$ conditional on the free trade agreement as $V(t) \equiv \int_{t}^{\infty} e^{-\rho s} \pi^{*}(s, \tau(s)) d s$, where $\tau(t)=\tau^{1}$ for $t \in\left[0, t^{*}\right)$ and $\tau(t)=0$ for $t \in\left[t^{*}, \infty\right)$. Note that $V(t)$ is continuous, despite the discontinuity in $(t)$. Assume that $V\left(t^{*}\right)>F_{\min }$, so that the agreement makes entry in $X$ potentially profitable for some industries, but $\pi^{*}\left(t^{*}, 0\right)<\rho F_{\min }$, so that for all industries, the ideal time to enter is sometime after the date the agreement comes into force; and $V(0)<F_{\min }$, so that for all industries, entry at the announcement date is unprofitable. Consider the dynamic game in which each of the two firms in industry $i$ picks its entry date conditional on the other firms not having entered yet. The only equilibrium in pure strategies is one in which entry occurs as soon as $V(t)=F_{i}$. This condition 
implicitly defines an entry date, $t_{i}$, for each industry $i$, and allows us to compute the equilibrium number of firms that have entered the $X$ market as of time $t, n(t) \equiv \int_{F_{\min }}^{V(t)} f(F) d f$. If the density $f$ has a standard quasi-concave bell shape with $f\left(F_{\min }\right)=f\left(F_{\max }\right)=0$, then the plot of $n(t)$ against time will have a continuous and monotonic $\mathrm{S}$ shape, beginning to rise at some date $t$ between the announcement and the tariff elimination, with $n(t)=0$; rising first more quickly, then more slowly thereafter, and then slowing down as it nears a new steady state. A similar pattern will be observed in country $X$ 's share of $Z$ 's exports, $\alpha_{X}(t) \equiv[n(t) p(t ; \tau(t)) x(t ; \tau(t))] /[n(t) p(t ; \tau(t)) x(t ; \tau(t))+\bar{p} \bar{x}]$. The time path for $\alpha_{X}:(i)$ will begin to adjust to the news of the free trade area at $t=t^{\prime}<t^{*}$; (ii) will adjust continuously, except at $t=t^{*}$, at which point it will jump up discontinuously; ${ }^{33}$ (iii) will be monotonically increasing; and (iv) will decelerate toward a zero rate of change as the new steady-state is approached. In this sense, it will be either ' $\mathrm{S}$ '-shaped or quite close to it.

Thus, the broad outlines of the aggregate adjustment in the two cases are similar. The trade share $\alpha_{X}$ begins to rise before the trade agreement comes into force, because of anticipatory investment. Its direction of movement is upward overall, and it is continuous except at the actual accession date, because of a discontinuous movement in trade impediments, and hence in prices, on that date. Finally, this adjustment is slower at its beginning and end than in between.

\footnotetext{
${ }^{33}$ This is, of course, because of the removal of the tariff at that date, which causes a discontinous increase in quantity sold and in revenues received by each firm that has already entered as of that date.
} 
Table 1: Piecewise linear regression for the EU

\begin{tabular}{|c|ccccc|}
\hline & Inten & Share & Core & First Expansion & Final Expansion \\
\hline$s_{0}$ & $-2.51^{*}$ & $-4.11^{*}$ & $-6.94^{*}$ & $-6.95^{*}$ & $-5.00^{*}$ \\
& $(0.753)$ & $(0.520)$ & $(0.831)$ & $(1.401)$ & $(1.348)$ \\
$s_{1}$ & $9.54^{*}$ & $7.42^{*}$ & $8.73^{*}$ & $13.57^{*}$ & \\
& $(0.767)$ & $(0.530)$ & $(0.632)$ & $(1.492)$ & \\
$\beta_{1}$ & $0.044^{*}$ & $0.016^{*}$ & $0.014^{*}$ & $0.009^{*}$ & $0.013^{*}$ \\
& $(0.004)$ & $(0.001)$ & $(0.001)$ & $(0.001)$ & $(0.002)$ \\
\hline nob & 528 & 528 & 245 & 147 & 147 \\
MSE & 0.030 & 0.002 & 0.001 & 0.002 & 0.004 \\
\hline
\end{tabular}

Notes: regressions were run with country fixed effects, values for the constants are not reported. Asymptotic standard errors are in parentheses. 
Table 2: Anticipation in the EU

\begin{tabular}{|c|c|c|c|c|}
\hline $\mathrm{s}$ & Share & Inten & Share & Inten \\
\hline \multirow[t]{2}{*}{-5} & 0.005 & 0.024 & 0.004 & $0.063^{* *}$ \\
\hline & $(0.79)$ & (1.07) & $(0.63)$ & $(2.75)$ \\
\hline \multirow[t]{2}{*}{-4} & 0.013 & 0.036 & $0.016^{*}$ & 0.046 \\
\hline & $(1.60)$ & (1.19) & $(2.04)$ & $(1.46)$ \\
\hline \multirow[t]{2}{*}{-3} & $0.021^{*}$ & 0.058 & $0.026^{* *}$ & $0.105^{* *}$ \\
\hline & $(2.17)$ & (1.62) & $(2.77)$ & $(2.83)$ \\
\hline \multirow[t]{2}{*}{-2} & $0.021^{*}$ & 0.033 & $0.024^{*}$ & $0.087^{*}$ \\
\hline & (1.97) & $(0.84)$ & $(2.28)$ & $(2.09)$ \\
\hline \multirow[t]{2}{*}{-1} & $0.031^{* *}$ & 0.053 & $0.031^{* *}$ & $0.090^{*}$ \\
\hline & $(2.71)$ & (1.24) & $(2.79)$ & $(2.01)$ \\
\hline \multirow[t]{2}{*}{0} & $0.060^{* *}$ & $0.118^{* *}$ & $0.063^{* *}$ & $0.097^{*}$ \\
\hline & $(4.95)$ & $(2.61)$ & $(5.30)$ & $(2.04)$ \\
\hline nob & 615 & 615 & 615 & 615 \\
\hline $\operatorname{Adj} R^{2}$ & 0.54 & 0.66 & 0.50 & 0.56 \\
\hline
\end{tabular}

Notes: First 2 columns estimate equation 4.1, second two columns estimate equation 4.1 excluding calendar year effects.

All regressions run with a correction for autocorrelation.

t-statistics in parentheses. ${ }^{*}$ Significant at the $5 \%$ level, ${ }^{* *}$ significant t the $1 \%$ level. 
Table 3: Hypothesis Tests for the EU

\begin{tabular}{|l|ll|}
\hline & Share & Inten \\
\hline A5 & 0.02 & 0.16 \\
A4 & 0.02 & 0.17 \\
A3 & 0.01 & 0.19 \\
B1 & 0.008 & 0.02 \\
B2 & 0.08 & 0.09 \\
\hline
\end{tabular}

Notes: This table reports the marginal significance levels of hypothesis tests of the specifications reported in figures 4.1 and 4.2. Each test is calculated by computing the appropriate Wald statistic $\chi^{2}(1)$. A5-A3 Hypothesis: preaccession effects sum to zero in five, four, and three years before accession. B1: Hypothesis: the gain in trade share in "year zero" is equal to the average gain. B2: First differences. Hypothesis: the estimate of the coefficient on "year zero" is equal to the average coefficient. 
Table 4: Piecewise linear regression for other unions

\begin{tabular}{|c|c|c|c|c|}
\hline & \multicolumn{2}{|c|}{ EFTA } & \multirow{2}{*}{$\begin{array}{c}\text { MERCOSUR } \\
\text { Share }\end{array}$} & \multirow{2}{*}{$\begin{array}{c}\text { NAFTA } \\
\text { Share }\end{array}$} \\
\hline & Share & Inten & & \\
\hline \multirow[t]{2}{*}{$s_{0}$} & -0.457 & 0.457 & $-2.78^{*}$ & $-11.73^{*}$ \\
\hline & $(0.981)$ & $(0.668)$ & $(1.38)$ & $(1.190)$ \\
\hline \multirow[t]{2}{*}{$s_{1}$} & $9.503^{*}$ & $12.413^{*}$ & & \\
\hline & $(0.613)$ & $(0.536)$ & & \\
\hline \multirow[t]{2}{*}{$\beta_{1}$} & $0.006^{*}$ & $0.080^{*}$ & $0.017^{*}$ & $0.008^{*}$ \\
\hline & $(0.001)$ & $(0.007)$ & $(.005)$ & $(0.001)$ \\
\hline \multirow[t]{2}{*}{$\beta_{2}$} & $-0.004^{*}$ & -0.024 & & \\
\hline & $(0.000)$ & $(0.003)$ & & \\
\hline nob & 386 & 386 & 124 & 77 \\
\hline MSE & 0.0006 & 0.056 & 0.0035 & 0.0006 \\
\hline
\end{tabular}

Notes: regressions were run with country fixed effects, values for the constants are not reported.

Asymptotic standard errors are in parentheses. 
Table 5: Anticipation in the EFTA

\begin{tabular}{|c|c|c|}
\hline $\mathrm{s}$ & Share & Inten \\
\hline \multirow[t]{2}{*}{-5} & -0.006 & 0.051 \\
\hline & $(-1.28)$ & $(1.40)$ \\
\hline \multirow[t]{2}{*}{-4} & -0.009 & $0.098^{*}$ \\
\hline & $(-1.36)$ & (1.95) \\
\hline \multirow[t]{2}{*}{-3} & 0.0007 & 0.226 \\
\hline & $(0.089)$ & $(3.75)$ \\
\hline \multirow[t]{2}{*}{-2} & 0.006 & 0.117 \\
\hline & $(0.705)$ & $(1.71)$ \\
\hline \multirow[t]{2}{*}{-1} & 0.011 & $0.135^{*}$ \\
\hline & (1.08) & $(1.80)$ \\
\hline \multirow[t]{2}{*}{0} & $0.021^{* *}$ & $0.180^{* *}$ \\
\hline & (1.98) & $(2.18)$ \\
\hline nob & 528 & 528 \\
\hline $\operatorname{Adj} R^{2}$ & 0.87 & 0.81 \\
\hline
\end{tabular}

This table reports the anticipatory effects when regression equation 4.1 is run on EFTA, excluding calendar year effects and including country-specific trends.

Notes: all regression were run with a correction for autocorrelation.

t-statistics are in parentheses. ${ }^{* *}$ significant at the $1 \%$ level, ${ }^{*}$ significant at the $10 \%$ level. 
Table 6: Hypothesis tests EFTA

\begin{tabular}{|c|cc|}
\hline & shrtrnd & intrnd \\
\hline A & 0.01 & 0.48 \\
B & 0.41 & 0.80 \\
\hline
\end{tabular}

Notes: This table reports the marginal significance levels of hypothesis tests of the specifications reported in figures 4.3 and 4.4. Each test is calculated by computing the appropriate Wald statistic $\chi^{2}(1)$.

A Hypothesis: preaccession effects sum to zero three years before accession, respectively.

B Hypothesis: the gain in trade share in "year zero" is equal to the average gain. 
Figure 1: EU Median Trade Shares and Median Trade Intensity Indices

Trade Shares

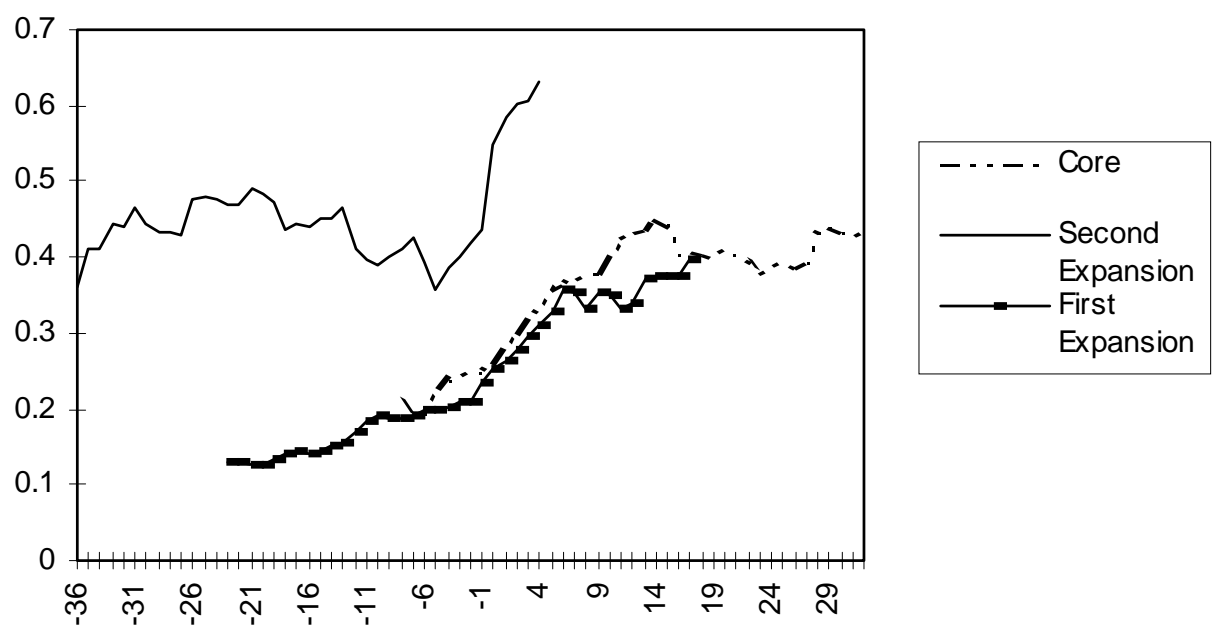

Trade Intensity Indices

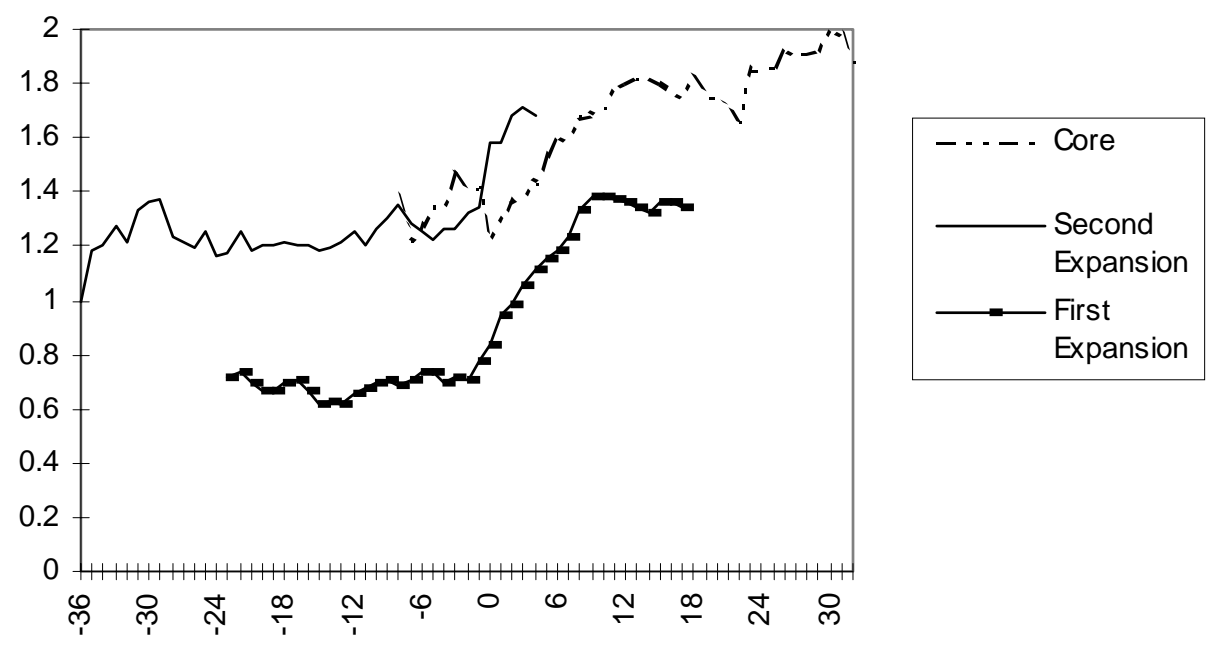

Note: since the second expansion occurred in 1986, the data end in mid-adjustment for those countries. 
Figure 2: EFTA Median Trade Share and Median Trade Intensity Index

\section{Trade Share}

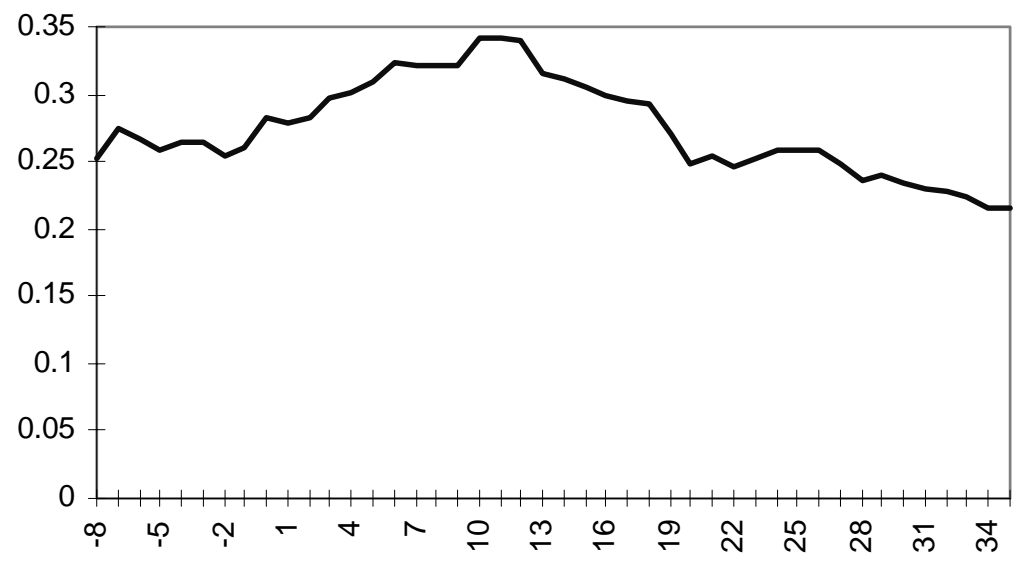

Intensity Index

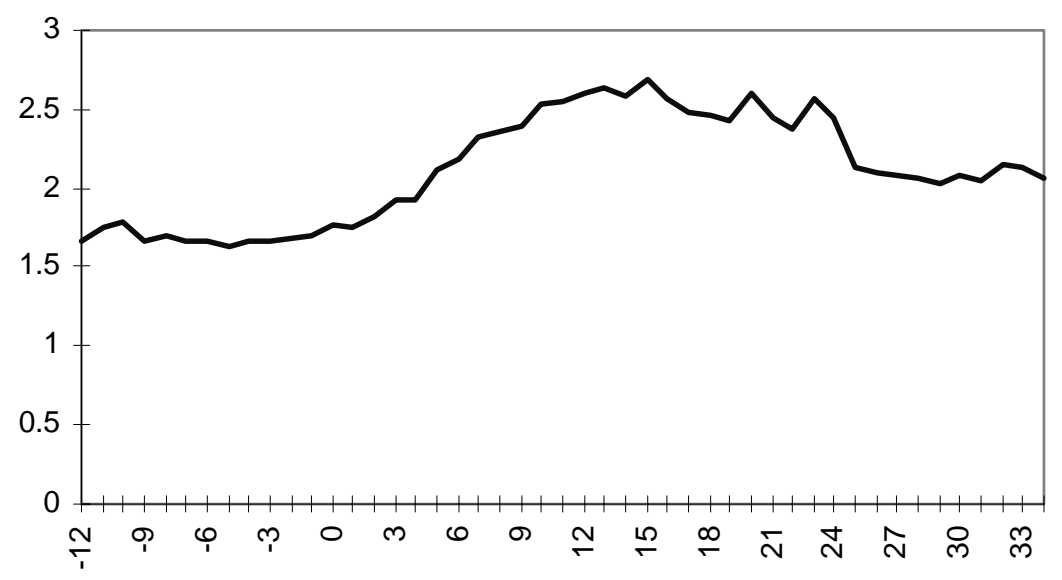


Figure 3: MERCOSUR Median Trade Share and Median Trade Intensity Index

\section{Trade Share}

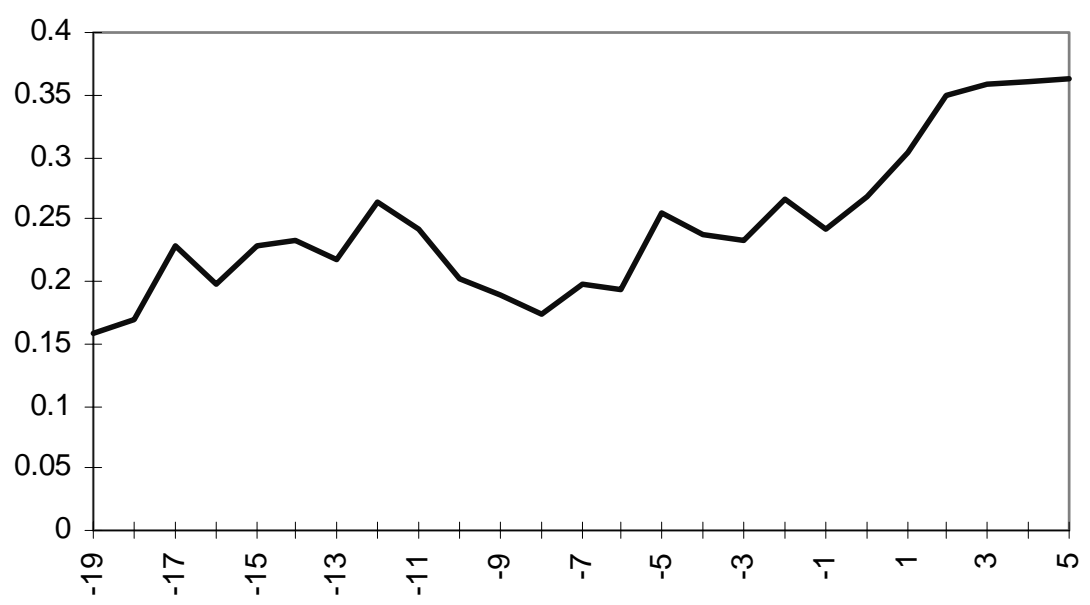

Trade Intensity Index

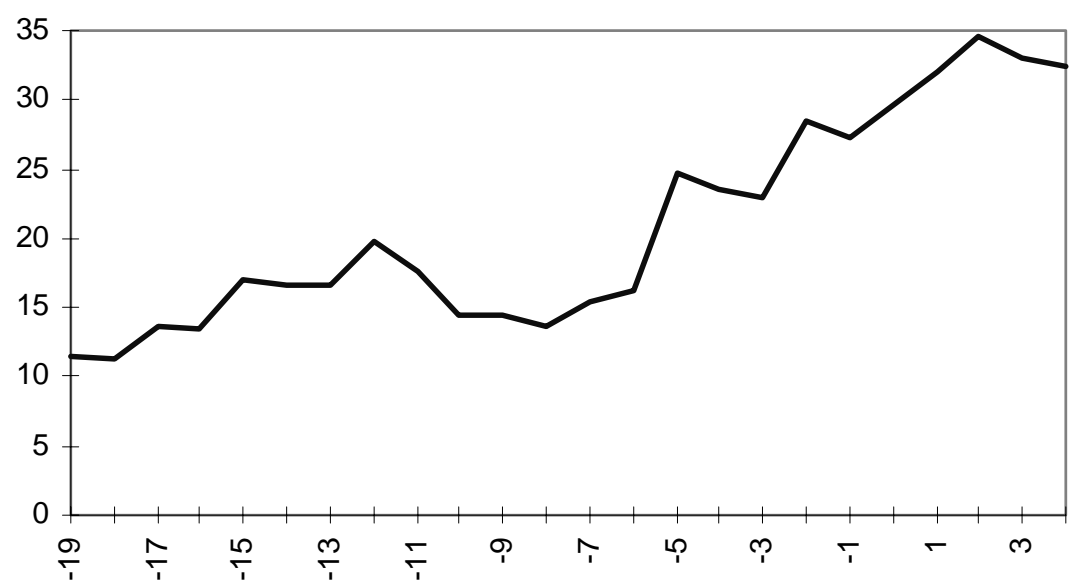


Figure 4: NAFTA Median Trade Share and Median Trade Intensity Index

\section{Trade Share}

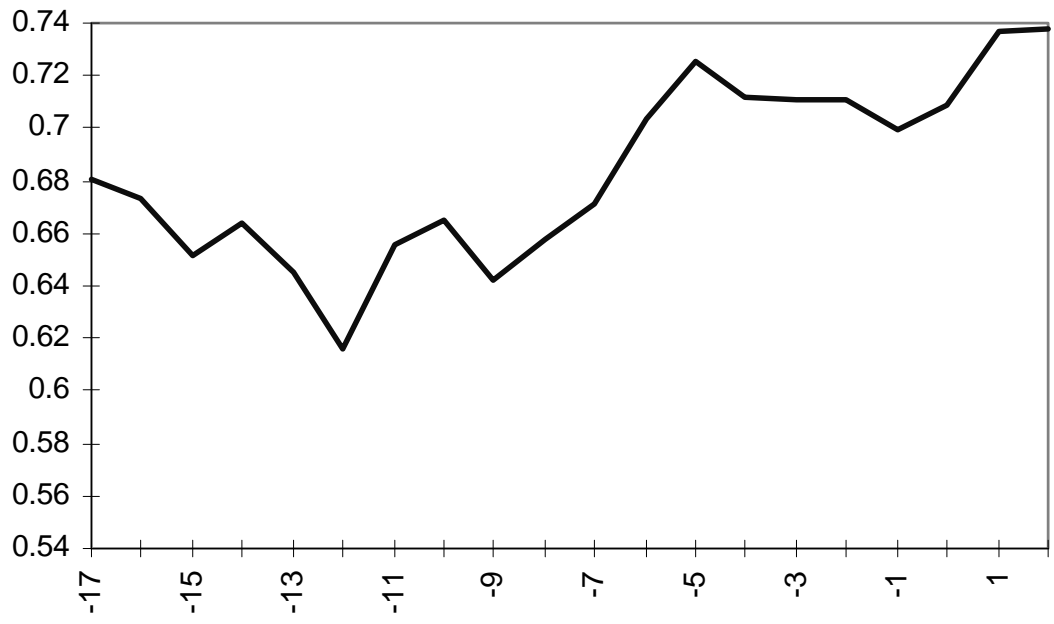

Trade Intensity Index

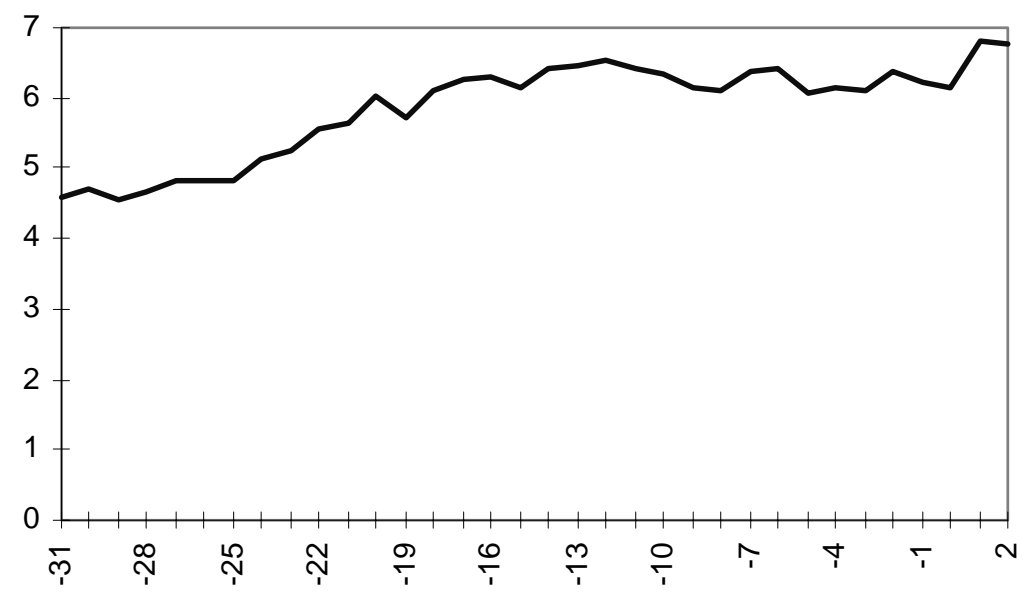


Figure 5: Median Trade Intensity Indices, Non-Unions

\section{EU Non-Members*}

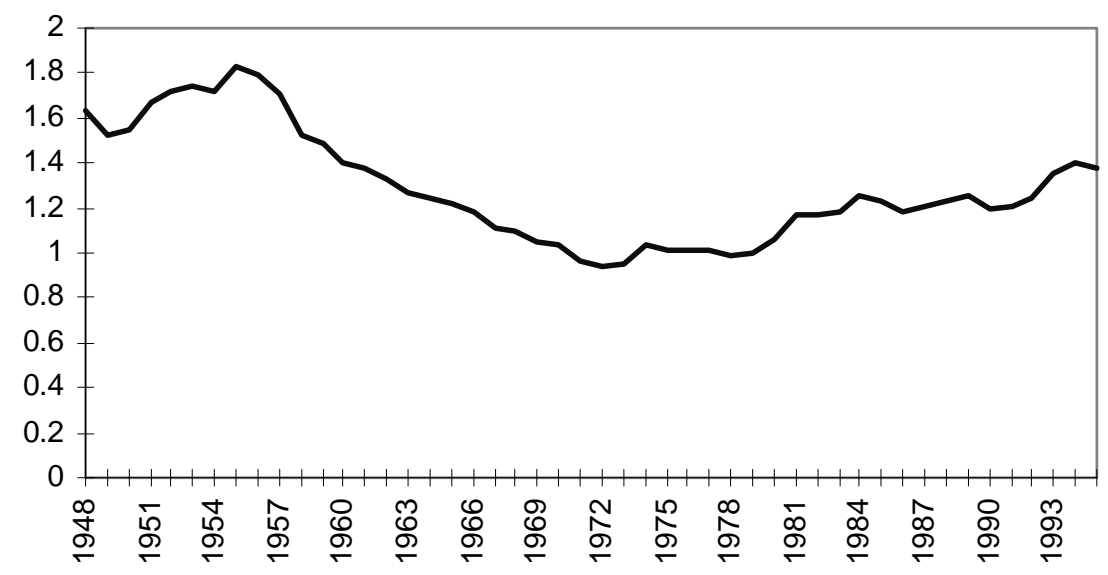

Asia **

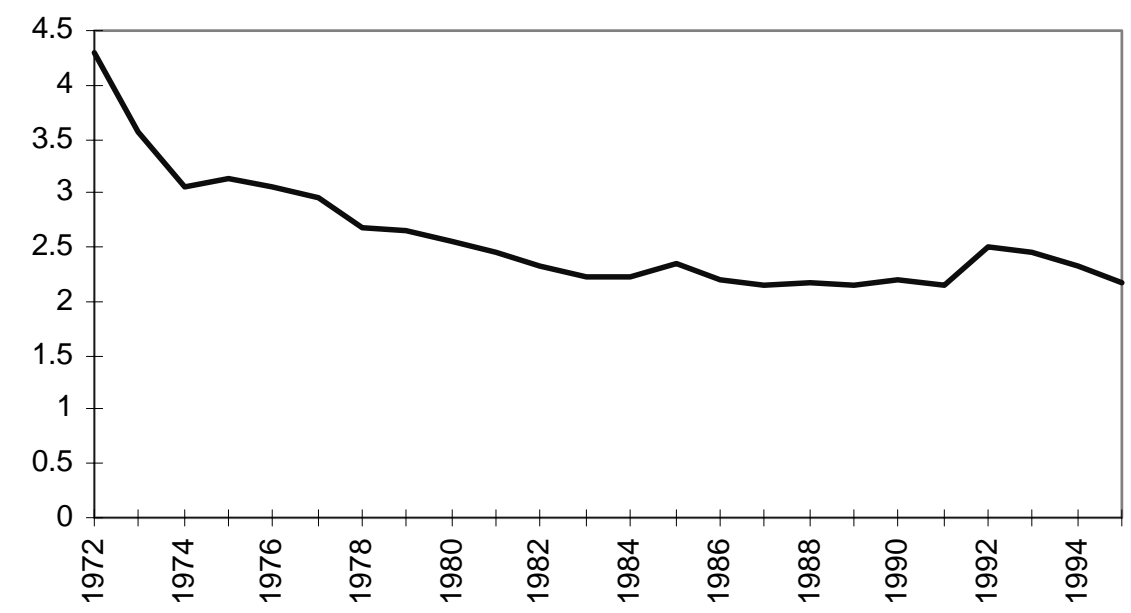

* Median trade intensity indices among European countries with core EU members, including: Finland, Norway, Sweden, and Switzerland.

** Median trade intensity index among East Asian Countries, including: Hong Kong, Korea, Thailand, and Japan. 
Figure 6: Estimated Adjustment Profile for the EU

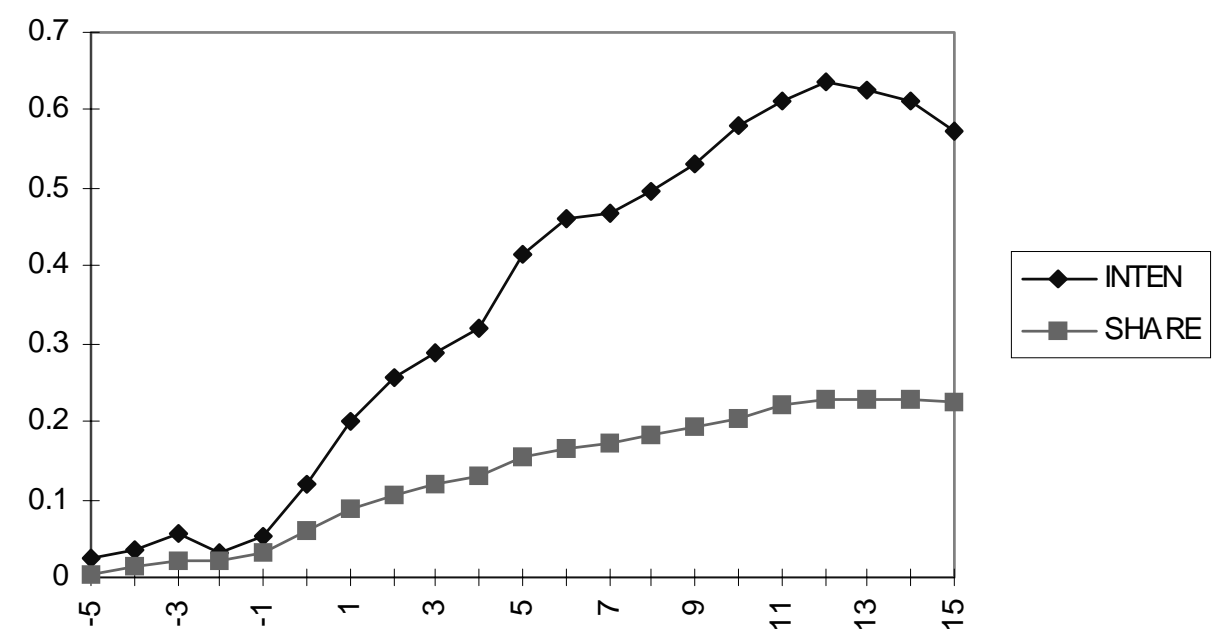

Figure 7: Estimate of First Differences in Shares for the EU

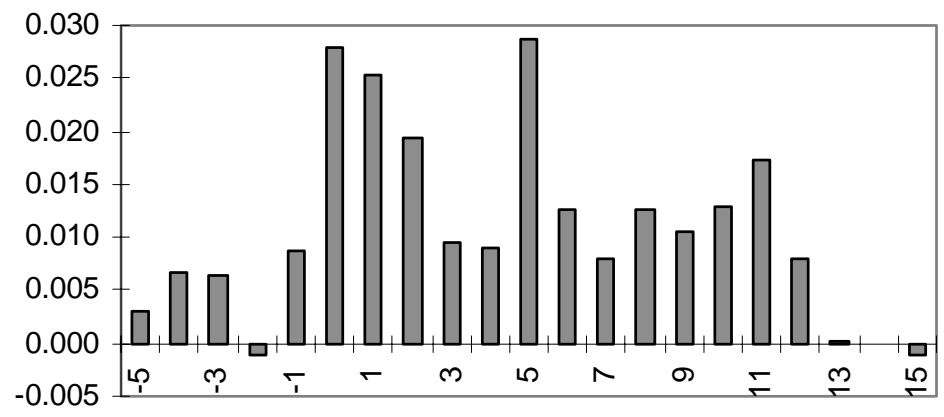


Figure 8: Estimated Adjustment Profile for EFTA

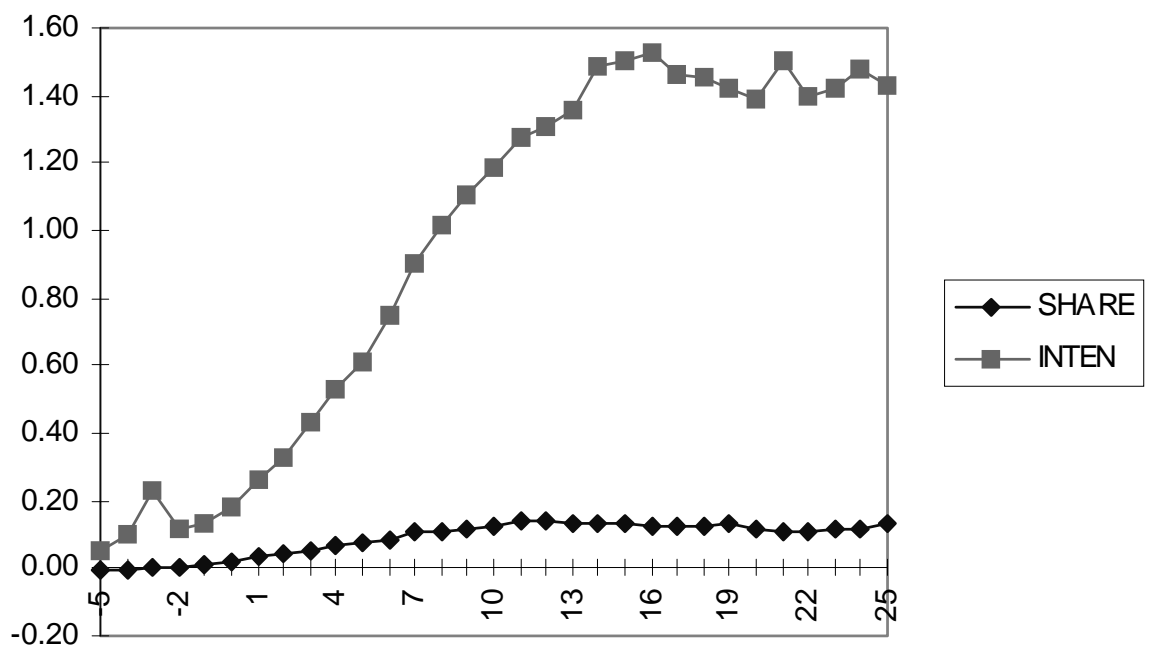




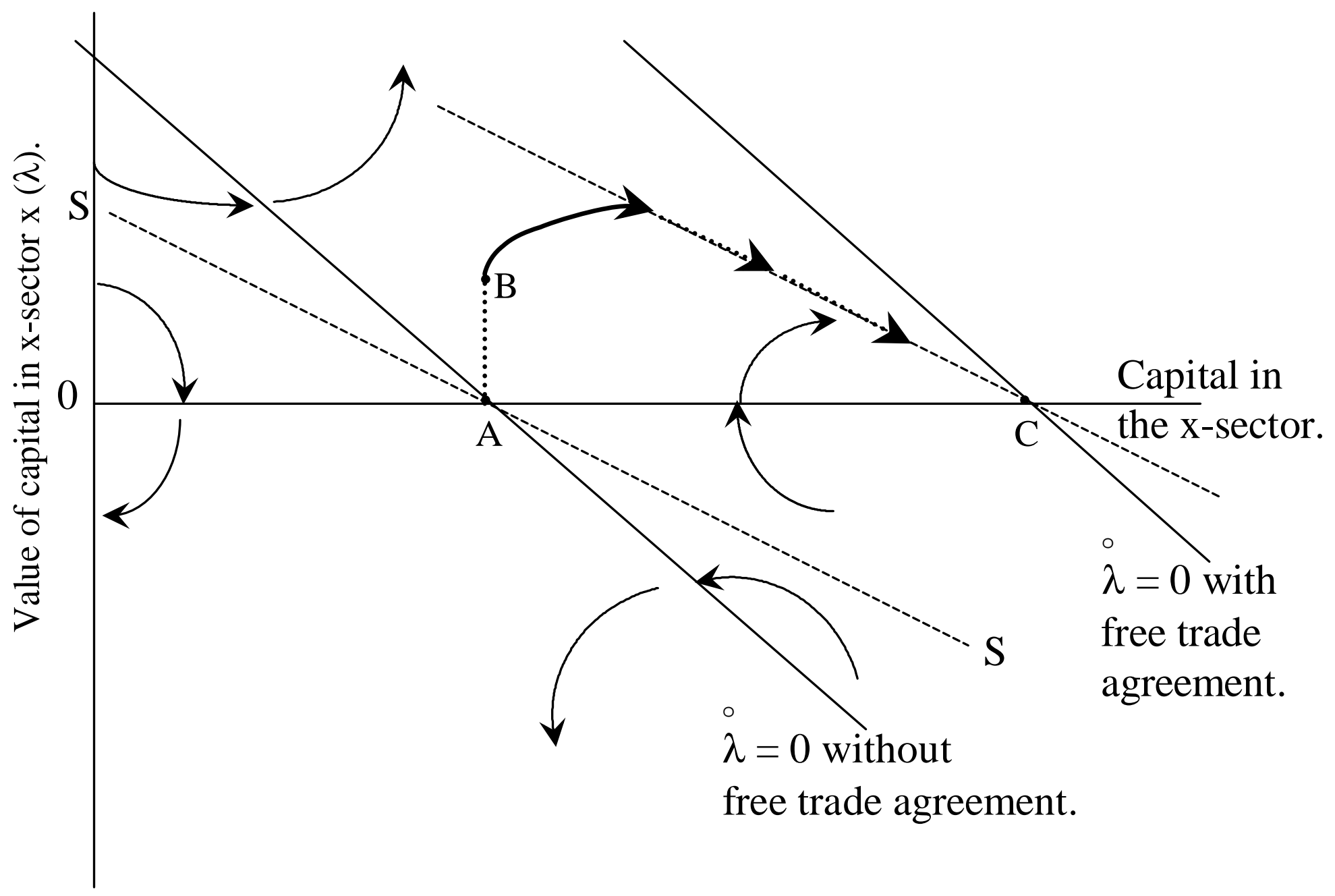

Figure A1. The convex adjustment cost model. 